\title{
Pembatalan pada Peralihan Hak Milik Atas Dasar Hibah
}

\author{
Luna Alifia Khansa ${ }^{1}$, Surahmad ${ }^{2}$ \\ ${ }^{1,2}$ Fakultas Hukum, Universitas Pembangunan Nasional Veteran Jakarta \\ Jl. RS. Fatmawati Raya, Pd. Labu, Kec. Cilandak, Kota Depok, Jawa Barat 12450 \\ Correspondence email: lunaalifiak@upnvj.ac.id; surahmad1970@gmail.com
}

\begin{abstract}
Abstrak. Hibah merupakan pemberian suatu kepemilikan dari si pemberi hibah kepada penerima hibah secara Cuma-Cuma dan dilakukan saat pemberi hibah masih hidup. Hibah dapat dituangkan dalam 2 akta yaitu akta otentik dan akta bawah tangan yang memiliki kepastian hukum yangberbeda. Legalitas akta hibah yang dilakukan dibawah tangan serta alasan pembatalan hibah yang banyak terjadi tidak dijelaskan secara rinci dalam Peraturan perundang-undangan. Walau pembatalan hibah telah ditekankan karena tidak dapat kembali dengan pengecualian pada pasal 1688, tetapi pada prakteknya masih saja terdapat kasus yang memohon pembatalan hibah karena berbagai macam hal. Tujuan penelitian ini adalah untuk memberikan informasi mengenai legalitas hibah bawah tangan dan apa saja yang dapat membatalkan hibah. Metode penelitian yang digunakan dalam penelitian ini adalah yuridis normatif dengan pendekatan perundang-undangan. Hasil dari penelitian ini adalah akta dibawah tangan tetap dianggap sah, namun pada saat melakukan pendaftaran menurut PP No.24 Tahun 1997 tetap harus menggunakan akta yang dibuat oleh PPAT. Kemudian alasan Pembatalan hibah sendiri tidak hanya yang diatur dalam Pasal 1688 KUHperdata saja, tetapi ada alasan lain yang mengakibatkan pembatalan hibah seperti cacat hukum administratif, hibah melebihi batas legitime portie, dan lain sebagainya.
\end{abstract}

Kata-kata Kunci: Hibah; Pembatalan; Legalitas; Akta Bawah Tangan

\begin{abstract}
The grant would be an outright gift from the giver to the gritty and while the giver was still alive. The grant can be poured in 2 deeds which are authentic deeds and under hands which have a different legal certainty. The legality of handheld grants and the reason for the cancellation of many are not specified in the regulations. Although the cancellation of the grant has been emphasized for not being able to return with an exception in article 1688 code civil, there still remains in practice a case requesting the cancellation of the grant for various things. The purpose of this research is to provide information regarding the legality of the grants under the hands and anything that might invalidate the grant. The study method used in this study was normative-juridical with a constitutional approach. The results of this study are under his hands still valid, but at the time of registration according to page no.24 of 1997 still have to use a deed made by ppat. Then the reason for the cancellation of the grant itself is not only admissible in article 1688 code civil, but there is another reason for the cancellation of grants such as administrative law cacies, grants exceeding the limit of legitme portie, and so on.
\end{abstract}

Keywords: Grant, annulment, legality, deed under hand

\section{PENDAHULUAN}

Menurut Kamus Besar Bahasa Indonesia, Tanah adalah permukaan bumi atau lapisan bumi yang di atas sekali. ${ }^{1}$ Urusan pertanahan telah diatur oleh pemerintah dalam Undang-undang Nomor 5 Tahun 1960. Undang-undang ini dikenal dengan nama Undang-undang Pokok Agraria (UUPA). Tanah memiliki berbagai arti yang kemudian harus diberi batasan. Maka dari itu secara resmi UUPA membatasi pengertian tanah yang dicantumkan dalam Pasal 4 ayat (1). Dalam Pasal ini, menjelaskan bahwa berdasarkan hak yang negara berikan untuk menguasai hak atas tanah, ada berbagai macam hak atas permukaan bumi yang disebut tanah, yang dapat dimiliki oleh orang-orang baik untuk dimiliki sendiri ataupun dimiliki bersama dengan orang lain atau dengan badan hukum. ${ }^{2}$

Berdasarkan hal yang sudah dijelaskan diatas dapat disimpulkan bahwa pengertian tanah dalam sudut pandang yuridis adalah permukaan bumi. Tanah juga termasuk kedalam kebutuhan primer manusia. Semua orang akan berlomba-lomba berusaha untuk mendapatkan tanah guna dimanfaatkan sesuai fungsinya. Dalam UUPA sendiri diatur mengenai jenis-jenis hak atas tanah yaitu Hak Milik, Hak Guna Bangunan, Hak Guna Usaha, Hak Pakai, Hak membuka Tanah dan memungut hasil hutan, serta hak guna air pemeliharaan dan penangkapan ikan. ${ }^{3}$

Berbagai jenis-jenis hak atas tanah tersebut dapat diambil alih atau dialihkan melalui pendaftaran hak atas tanah. Pendaftaran hak atas tanah dapat dilakukan langsung dengan datang ke kantor pertanahan yang mengatur wilayah dimana tanah tersebut berada. Pendaftaran tanah sendiri sudah diatur dalam Peraturan Pemerintah Nomor 24 Tahun 1997 tentang Pendaftaran Tanah. Pendaftaran tersebut memiliki fungsi untuk melindungi hak-hak kepemilikan tanah seseorang.

\footnotetext{
${ }^{1}$ Kamus Besar Bahasa Indonesia

2 Undang-undang Nomor 5 Tahun 1960 tentang Pokok-Pokok Agraria

${ }^{3}$ Siti Nurul Intan. dan Wardani Rizkianti. "STUDI KOMPARATIF PENDAFTARAN HAK TANGGUNGAN DI KOTA BOGOR DAN KOTA DEPOK”, Jurnal Yuridis, Vol.6, No.2 (2019): 191
} 
Pada proses pendaftaran tanah, pengubahan nama dalam sertifikat hak milik atau balik nama disebut juga sebagai peralihan hak. Pada pasal 37 ayat (1) PP Nomor 24 Tahun 1997 menyatakan bahwa "peralihan hak atas tanah dan hak milik atas satuan rumah susun dapat dilakukan melalui jual-beli, tukar menukar, hibah, pemasukan dalam perusahaan dan perbuatan hukum pemindahan hak lainnya, kecuali pemindahan hak melalui lelang, yang hanya dapat didaftarkan jika sudah dibuktikan dengan adanya akta yang dibuat oleh PPAT yang berwenang."

Sebelum lahir PP No. 24 Tahun 1997 Tentang Pendaftaran Tanah, bagi masyarakat yang tunduk pada KUH Perdata surat hibah harus dibuat dalam bentuk tertulis dari notaris. Apabila ada hibah yang tidak dilakukan di hadapan notaris, maka surat tersebut memiliki kekuatan pembuktian yang kuat. Bagi orang-orang yang tunduk pada hukum adat dapat akta hibah dibawah tangan tetapi saat melakukan proses pendaftaran di KanTah harus dibuat dengan akta PPAT. Setelah Lahirnya PP No. 24 Tahun 1997 setiap pemberian hibah harus dilakukan dengan akta PPAT.

Pada penghibahan, orang yang menghibahkan dilarang untuk memberikan persyaratan bahwa, si penghibah masih memiliki kuasa atas tanah tersebut. Meskipun dalam pengertiannya, hibah tidak diperbolehkan untuk ditarik kembali, ada beberapa pengecualian yang memungkinkan penghibahan dapat ditarik Kembali. Pengecualian tersebut dijelaskan dalam "Pasal 1688 KUH Perdata, yaitu :

a. Karena syarat-syarat penghibahan yang tidak dipenuhi

b. Jika si penerima hibah telah bersalah melakukan atau membantu melakukan kejahatan yang bertujuan mengambil jiwa si penghibah atau suatu kejahatan lain (misalnya penistaan) terhadap si penghibah

c. Jika ia menolak memberikan tunjangan nafkah kepada si penghibah, setelah orang ini jatuh dalam kemiskinan."

Penarikan Kembali dilakukan dengan menyatakan keputusannya kepada si penerima hibah disertai dengan tuntutan pengembaliannya barang yang telah dihibahkan yang dalam hal ini adalah tanah. ${ }^{5}$

Dalam penelitian ini, penulis akan membahas mengenai legalitas hibah yang tidak dituangkan dalam akta otentik atau dibuat di bawah tangan, serta hal-hal apa saja yang dapat membatalkan hibah dalam peraturan perundangundangan yang mengatur hal tersebut.

\section{METODE}

\section{Jenis Penelitian}

Penelitian ini menggunakan penelitian hukum normatif atau Yuridis Normatif. Kajian utamanya adalah hukum yang ditentukan sebagai aturan yang berlaku dalam lingkungan sosial dan menjadi tolak ukur perilaku setiap orang. Sehingga penelitian hukum normatif memiliki tujuan utama pada inventarisasi hukum positif, asas-asas dan doktrin hukum, penemuan hukum dalam perkara in concreto, sistematik hukum, taraf sinkronisasi, perbandingan hukum dan sejarah hukum. ${ }^{6}$ Dari penjelasan yang penulis jelaskan diatas maka penulis memilih untuk menggunakan penelitian hukum normatif dalam melakukan penelitian dan menulis hasil dari penelitian ini. Pendekatan yang penulis gunakan dalam penelitian ini adalah pendekatan perundang-undangan, penulis akan meneliti sesuai fakta-fakta yang ditemukan dalam masyarakat dengan perundang-undangan yang memang terkait dengan hal tersebut

\section{Jenis Pengumpulan Data}

Dalam penelitian ini, bahan hukum dikumpulkan melalui identifikasi perundang-undangan, klasifikasi serta sistematika bahan hukum yang sesuai dengan penelitian yang dilakukan oleh Penulis. Maka dari itu, penelitian ini menggunakan teknik pengumpulan data yaitu studi kepustakaan yang dilakukan dengan cara membaca, mencari informasi, menyimpulkan bacaan, serta membuat catatan terkait materi yang dibutuhkan pada penelitian ini. Sumber data yang digunakan oleh penulis ialah data sekunder yaitu Undang-Undang No.5 Tahun 1960 tentang Pokok-Pokok Agraria , Peraturan Pemerintah No. 24 Tahun 1997 tentang Pendaftaran Tanah, Peraturan Menteri Negara Agraria Nomor 9 Tahun 1999 tentang tata cara pemberian dan pembatalan hak atas tanah Negara dan hak pengelolaan, Jurnal Ilmiah Terdahulu serta Buku Teks. Penulis akan menganalisa data yang didapat dari penelitian studi kepustakaan tersebut dengan metode deskriptif analisis, yaitu menuliskan data dalam bentuk kata-kata yang kemudian dideskripsikan untuk memberikan informasi yang jelas terkait topik penelitian penulis berdasarkan hukum positif yang berlaku di Indonesia.

\section{HASIL DAN PEMBAHASAN}

\section{Legalitas Akta Hibah Yang Tidak Dituangkan Dalam Akta Otentik Atau Dibuat Dalam Akta Bawah Tangan}

Peralihan hak atas tanah bisa terjadi dengan berbagai cara, diantaranya adalah melalui jual beli, hibah, sewa menyewa, tukar menukar dan lain sebagainya. Peralihan hak tersebut terjadi dengan adanya kesepakatan para pihak dimana hal tersebut menjadi syarat sah dalam sebuah perjanjian yang diatur dalam Pasal 1320 KUH Perdata. Dalam

\footnotetext{
${ }^{4}$ Waskito,dkk. Pertanahan, Agraria, dan Tata Ruang. (Jakarta: Kencana, 2017), hal. 162

5 Ibid., hal. 166-167

${ }^{6}$ Muhammad Abdulkadir, Hukum dan Penelitian Hukum, Cet. 1. (Bandung: PT. Citra Aditya Bakti, 2004$)$, hal. 52.
} 
Jurnal ini akan dibahas lebih lanjut mengenai hibah, Hibah diatur dalam Buku III BAB X yaitu dalam Pasal 1666 sampai Pasal 1693. Pada Pasal 1666 Kitab Undang-Undang Hukum Perdata menyebutkan pengertian hibah sebagai berikut:

"Hibah adalah Suatu persetujuan dengan mana seorang penghibah menyerahkan suatu barang secara cumacuma, tanpa dapat menariknya kembali, untuk kepentingan seseorang yang menerima penyerahan barang itu. Undangundang hanya mengakui penghibahan-penghibahan antara orang-orang yang masih hidup".

Berdasarkan pengertian diatas, dapat disimpulkan bahwa hibah dilakukan oleh seorang secara Cuma-Cuma dan barang yang sudah dihibahkan tidak dapat ditarik kembali. Hibah terdiri dari berbagai macam yaitu :

a. Hibah Manfaat, hibah ini diberikan ketika sebuah hadiah diberikan secara Cuma-Cuma dengan harapan harta tersebut dapat bermanfaat bagi kehidupan si penerima hibah. Jika si penerima hibah meninggal lebih dulu daripada pemberi hibah, maka barang tersebut dikembalikan lagi kepada si pemberi hibah.

b. Hibah barang, hibah ini diberikan kepada si penerima hibah dengan nilai materi atau manfaat, tanpa harapan apapun. $^{7}$

Hibah juga memiliki syarat utama yaitu :

a. Pemberi hibah harus sudah cakap atau dianggap telah dewasa secara hukum atau sudah menikah

b. Sesuatu yang akan dihibahkan harus sudah ada ketika hibah tersebut akan di laksanakan

c. Sesuatu yang akan dihibahkan harus bermanfaat bagi penerima hibah

Syarat yang lain secara tidak langsung disebutkan pada Pasal 1666 KUH Perdata yaitu hibah dianggap sah jika dilakukan diantara orang-orang yang masih hidup. Apabila salah satu pihak dalam pelaksanaan hibah meninggal, maka hibah dikatakan tidak sah karena tidak memenuhi syarat.

Kemudian, seperti yang kita ketahui Indonesia merupakan sebuah Negara menjunjung tinggi hokum atau Peraturan. Hal tersebut diatur dalam Pasal 1 ayat (3) UUD 1945. Negara Hukum memiliki prinsip untuk menjaga keadilan dan perlindungan hukum dalam kepastian hukum itu sendiri. Kepastian, keadilan dan perlindungan hukum menuntut antara lain adanya lalu lintas hukum dalam kehidupan bermasyarakat karena masyarakat memerlukan alat bukti yang menentukan dengan jelas hak dan kewajiban seseorang sebagai subyek hukum dalam lingkungan sosial. ${ }^{8}$ Sebagai negara hukum, peraturan mengenai hibah juga ditentukan dalam Undang-Undang termasuk bagaimana hibah tersebut di proses dan dalam bentuk apa hibah tersebut dapat dituliskan sehingga dapat menjadi bukti yang kuat untuk melindungi hak-hak para pihak. Pada pelaksanannya sebelum diterbitkannya Peraturan Pemerintah No.24 Tahun 1997 tentang Pendaftaran Tanah,Hibah dapat dituangkan dalam 2 bentuk akta, antara lain Akta Otentik atau Akta dibawah tangan.

Masyarakat yang tunduk pada Hukum Perdata surat hibah harus dibuat dalam bentuk tertulis atau dapat dikatakan akta otentik dan dibuat dihadapan Notaris. Jika tidak dibuat oleh Notaris maka surat tersebut tidak memiliki kekuatan hukum. Akta otentik merupakan akta yang dibuat dihadapan notaris tempat akta itu dibuat dan dalam bentuk yang telah ditentukan oleh Undang-Undang. Menurut Pasal 1868 KUH Perdata, akta yang benar harus memenuhi persyaratan yaitu bersifat kumulatif atau harus mencakup semua hal yang dibutuhkan dalam pelaksanaan hibah tersebut. ${ }^{9}$ Dalam Pasal 1870 KUH Perdata, akta otentik memberikan pemilik sahnya kekuatan pembuktian yang sangat kuat karena memiliki kepastian hukum yang diakui secara sah serta menjelaskan secara lengkap tentang apa yang telah dituangkan dalam akta tersebut. Akta tersebut dapat menjadi bukti konkrit dan dapat dijadikan bukti wajib di dalam pengadilan. Dengan demikian, apabila ada yang mendalilkan bahwa akta otentik tersebut palsu maka orang tersebut harus membuktikan dalil tersebut. ${ }^{10}$

Lalu, bagi masyarakat yang masih tunduk pada hukum adat diperbolehkan membuat surat hibah tersebut dibawah tangan. Akta dibawah tangan merupakan akta yang dibuat tidak dihadapan pejabat yang berwenang, dan hanya ditandatangani para pihak saja. Akta yang tidak memenuhi syarat pada Pasal 1868 KUH Perdata, meskipun ditanda tangani oleh para pihak tetap tidak dapat dianggap sebagai akta otentik karena kekuatan pembuktiannya hanya

${ }^{7}$ Robiah Awaliyah. and Nadjematul Faizah.,. "Tinjauan Yuridis Perkara Pembatalan Hibah (Studi Kasus Putusan Nomor 467 K/Ag2017).” Al-Mizan: Jurnal Hukum dan Ekonomi Islam, 4(2), pp.108-130.

${ }^{8}$ Kiagus Yusrizal., "Tinjauan Hukum Terhadap Kekuatan Pembuktian Akta Di Bawah Tangan Dihubungkan Dengan Kewenangan Notaris Dalam Pasal 15 Ayat (2) Uu Nomor 30 Tahun 2004 Tentang Jabatan Notaris “ (Doctoral dissertation, program Pascasarjana Universitas Diponegoro). (2008)

9 Purnamasari. I. D, 2015, https://www.hukumonline.com/klinik/detail/ulasan/lt550c0a7450a04/akta-notaris-sebagai-aktaotentik/\#: : text=\%E2\%80\%9CSuatu\%20akta\%20otentik\%20adalah\%20suatu, kumulatif\%20atau\%20harus\%20meliputi\%20sem uanya.

${ }^{10}$ I Ketut Tjukup. , I wayan Bela Siki Layang., dkk. “Akta Notaris (Akta Otentik) Sebagai Alat Bukti Dalam Peristiwa Hukum Perdata”, Acta Comitas Jurnal Hukum Kenotariatan, vol.1 no.6 (2016) 
pada tulisan dibawah tangan. Tetapi saat akan melakukan pendaftaran peralihan hak atas tanah, harus dibuat dengan akta PPAT. ${ }^{11}$

Pada Tahun 1997, Pemerintah mengeluarkan PP No. 24 Tahun 1997 yang mengatur tentang "setiap pemberian hibah tanah harus dilakukan dengan akta PPAT yang kemudian didaftarkan di Kantor Pertanahan sebagai bentuk pengamanan hibah tanah." 12 Hal ini dilakukan oleh Pemerintah agar dapat memberikan kepastian hukum kepada pemilik hak atas tanah atas dasar hibah yang kemudian harus diterbitkan dalam bentuk sertifikat tanah. Sertifikat ini memiliki fungsi sebagai bukti yang kuat mengenai data fisik dan data yuridis dari tanah yang terdaftar dalam sertifikat tersebut. Salah satu masalah yang berkaitan erat dalam pendaftaran tanah atas dasar hibah adalah masalah pembuktian, hal itu dapat terjadi karena adanya surat hibah yang dibuat dibawah tangan sebelum adanya PP No. 24 Tahun 1997 tersebut. ${ }^{13}$ Alas hak hibah yang dibuat dibawah tangan tidak diatur dalam HIR, tetapi diatur dalam staatsblad 1867 No.29 untuk Jawa dan Madura dan Pasal 286 sampai Pasal 305 RBg.

Pada akta hibah yang dibuat dibawah tangan, sejak terbit akta tersebut memiliki keterkaitan dengan tanda tangan para pihak yang berada di akta tersebut saja. Jika tanda tangan diakui, maka akta dibawah tangan tersebut memiliki kekuatan pembuktian yang sempurna. Begitu pula sebaliknya jika tanda tangan pada akta hibah bawah tangan tersebut tidak diakui oleh para pihak atau salah satu pihak maka akta tersebut tidak memiliki kekuatan pembuktian dan memungkinkan untuk disangkal. ${ }^{14}$ Kekuatan pembuktian atau keabsahan akta dibawah tangan dapat menjadi mutlak apabila akta tersebut dilegalisasi oleh Notaris. Secara umum akta dibawah tangan dibuat oleh para pihak saja, kemudian saat penandatangan dan atau cap jempol pada akta dilaksanakan di hadapan notaris. Setelah dilakukan legalisasi tersebut, para pihak hanya bertanggung jawab atas akta yang telah mereka buat demi kepentingan pribadi masing-masing. Sedangkan, Notaris yang menyaksikan penandatanganan akta hibah bawah tangan tersebut memiliki tanggung jawab sebatas pada kebeneran dan keabsahan tanda tangan para pihak pada akta tersebut. Notaris juga memiliki kewajiban untuk memastikan bahwa identitas para pihak pada akta hibah bawah tangan sudah sesuai dengan Kartu Identitas atau Kartu Tanda Penduduk milik Para Pihak. ${ }^{15}$

Berdasarkan penjelasan yang sudah diuraikan diatas, akta hibah bawah tangan memang dianggap dan diakui dalam KUH Perdata tetapi tidak memiliki kekuatan pembuktian yang sempurna. Akta bawah tangan dianggap sah karena pada dasarnya menurut "Pasal 1320 KUH Perdata menyebutkan bahwa :

Untuk sahnya suatu perjanjian diperlukan empat syarat:

1. Sepakat mereka yang mengikatkam dirinya

2. Kecakapan membuat suatu perikatan

3. Suatu hal tertentu

4. Suatu sebab yang Halal"

Salah satu yang dicantumkan dalam pasal tersebut adalah "sepakat mereka yang mengikatkan dirinya", maka dari itu akta hibah bawah tangan dapat dikatakan sah sepanjang pemberi hibah dan penerima hibah sepakat melaksanakan hibah tersebut. Kemudian, suatu perjanjian yang dibuat secara sah baik dilakukan dengan akta otentik maupun akta bawah tangan berlaku sebagai undang-undang bagi mereka yang membuatnya, hal ini diatur pada Pasal 1338 KUH Perdata. Jadi baik akta otentik maupun akta bawah tangan memiliki kedudukan yang sah menurut hukum positif di indonesia. ${ }^{16}$ Meskipun akta hibah bawah tangan dianggap sah menurut hukum dan perundang-undangan yang berlaku, berdasarkan PP No.24 Tahun 1997, pada pendaftaran hibah diwajibkan untuk melakukan pendaftaran dengan Akta PPAT, hal tersebut diperlukan untuk mempertahankan kepastian hukum bagi pemilik hak atas tanah hibah tersebut.

\section{Hal-hal yang dapat mengakibatkan Pembatalan Hibah}

Hibah yang sudah diberikan, harus dimuat dalam suatu akta hibah yang dibuat dihadapan notaris dengan format yang sudah ditentukan oleh Undang-Undang. Para pihak juga harus hadir dalam penanda tanganan akta tersebut. Jika salah satu pihak tidak hadir maka hibah tidak dapat dilaksanakan. Hibah yang sudah dilakukan harus didaftarkan ke Kantor Pertanahan. Menurut Pasal 37 ayat (1) PP No. 24 Tahun 1997 tentang Pendaftaran Tanah menyebutkan bahwa:

"Peralihan hak atas tanah dan hak milik atas satuan rumah susun melalui jual beli, tukar menukar, hibah, pemasukan dalam perusahaan dan perbuatan hukum pemindahan hak lainnya, kecuali pemindahan hak melalui lelang hanya dapat didaftarkan jika dibuktikan dengan akta yang dibuat oleh PPAT yang berwenang menurut ketentuan peraturan perundang-undangan yang berlaku."

\footnotetext{
${ }^{11}$ Effendi Perangin.,Mencegah Sengketa Tanah, (Jakarta: Rajawali, 1990) hal.56

12 Ahmad Sutedi, Sertifikat Hak Atas Tanah, (Jakarta: Sinar Grafika, 2017) hal.161

${ }^{13}$ Ahmad Sutedi., hal.176

${ }^{14}$ Ahmad Sutedi.,hal.179

15 Richard Cisanto Palit., "Kekuatan Akta di Bawah Tangan Sebagai Alat Bukti di Pengadilan. Lex Privatum" (2015) 3(2).

${ }^{16}$ Richard Cisanto Palit., hal.139
} 
Hal yang diatur dalam pasal tersebut berlaku untuk semua jenis peralihan Hak termasuk hibah bawah tangan yang diharuskan diubah menjadi akta PPAT untuk didaftarkan peralihan haknya, tetapi peraturan tersebut tidak berlaku untuk peralihan hak atas dasar lelang. Dalam pasal 1 PP No.24 Tahun 1997, "Pendaftaran tanah adalah rangkaian kegiatan yang dilakukan Oleh Pemerintah secara terus menerus, berkesinambungan dan teratur, meliputi pengumpulan, pengolahan, pembukuan, dan penyajian serta pemeliharaan data fisik dan data yuridis, dalam bentuk peta dan daftar, mengenai bidang-bidang tanah dan satuan-satuan rumah susun, termasuk pemberian surat tanda bukti haknya bagi bidang-bidang tanah yang sudah ada haknya dan hak milik atas satuan rumah susun serta hak-hak tertentu yang membebaninya."

Kemudian, menurut ahli yaitu Boedi Harsono, pendaftaran tanah merupakan suatu kegiatan pemerintahan yang beralur serta dilaksanakan secara terus menerus, berupa akumulasi data pertanahan yang antara lain merupakan proses peralihan hak yang berada pada suatu wilayah, bagi kepentingan rakyat dalam rangka memberikan kepastian dan perlindungan hukum bagi pemilik hak atas tanah tersebut. ${ }^{17}$ Berdasarkan Pasal 12 ayat (1) PP No.24 Tahun 1997, menjelaskan bahwa "kegiatan pendaftaran tanah untuk pertama kali meliputi kegiatan pengumpulan dan pengelolaan data fisik, pembuktian hak, penerbitan sertipikat, penyajian data fisik serta penyimpanan daftar umum dan dokumen." Pendaftaran tanah dalam peralihan hak memiliki beberapa tahapan yang harus dilakukan sebagai berikut:

a. Pengakuan tanah pertama kali

b. Pemeliharaan pendaftaran tanah.

c. Pembuatan peta dasar bidang yang menjadi dasar pendaftaran

d. Penetapan batas bidang-bidang tanah

e. Pengukuran dan pemetaan bidang-bidang tanah dan pembuatan peta pendaftaran

f. Pembuatan daftar tanah

g. Pembuatan surat ukur

h. Pembuktian hak baru ${ }^{18}$

Pada proses pendaftaran hibah tersebut bukan tidak mungkin terjadi sengketa antara penerima hibah dan para ahli waris yang tidak terima dengan penghibahan yang dilakukan oleh pemberi hibah semasa hidupnya. Sengketa atau permasalahan dapat terjadi karena berbagai macam hal yakni adanya kesalahpahaman antara penerima dengan ahli waris, hibah yang melebihi batas legitime portie, hibah yang cacat hukum administrasi dan lain sebagainya. Dengan adanya sengketa dalam peralihan hak hibah tersebut, maka para pihak yang bersengketa dapat mengajukan gugatan untuk menuntut pembatalan hibah yang sudah dilaksanakan. Menurut Pasal 1688 KUH Perdata menjelaskan bahwa "Suatu hibah tidak dapat ditarik kembali ataupun dihapuskan" tetapi hibah tetap dapat dibatalkan jika memenuhi beberapa atau salah satu hal yang mengakibatkan hibah tersebut dapat di batalkan yaitu :

a. Karena syarat-syarat penghibahan yang tidak terpenuhi. Pemberi hibah harus memenuhi persyaratan hibah yang telah diatur dalam Undang-Undang, karena jika syarat-syarat sah hibah tidak dipenuhi, maka hibah tersebut dapat dibatalkan atau ditarik kembali.

b. "Jika penerima hibah bersalah atau melakuka sesuatu yang mengancam nyawa si pemberi hibah atau melakukan suatu kejahatan yang lain. Saat penerima hibah melakukan kejahatan yang mengancam nyawa terhadap orang yang telah memberikan ia sebuah hadiah secara Cuma-Cuma maka hal tersebut tidak dapat dibiarkan sehingga dapat membatalkan hibah juga.

c. Jika penerima hibah menolak memberikan bantuan biaya hidup kepada si pengibah, setelah penghibah jatuh miskin. Dalam hal si penerima hibah menolak untuk memberikan nafkah kepada si pemberi hibah saat si pemberi hibah jatuh miskin atau perekonomiannya sedang menurun maka hibah juga dapat dibatalkan. Walaupun dalam penghibahan tidak diwajibkan untuk memberikan nafkah saat pemberi hibah jatuh miskin, tetapi sebagai manusia kita juga harus belajar bagaimana membantu sesama, terlebih lagi pada orang yang telah berbaik hati kepada kita. 19

Kemudian pada pasal 1690 KUH Perdata menyebutkan bahwa:

"Dalam kedua hal yang terakhir disebutkan dalam pasal 1688, tidaklah dapat diganggu gugat pemindahtanganan barang yang dihibahkan atau hipotik-hipotik dan lain-lain beban kebendaan, yang sekiranya telah diletakkan di atas barang tersebut oleh si penerima hibah sebelum tuntutan untuk pembatalan hibah telah didaftarkan di

17 Boedi Harsono, Hukum Agraria Indonesia, Sejarah Pembentukan Undang-Undang Pokok Agraria, Isi Dan Pelaksanaannya, Jilid I, Edisi Revisi, Cetakan Kesebelas, (Jakarta : Djambatan, 2007), hlm.72.

18 Rumah.com, 2019, Panduan Pendaftaran Tanah Sesuai PP 24 Tahun 1997, dalam https://www.rumah.com/panduanproperti/panduan-pendaftaran-tanah-sesuai-pp-24-tahun-1997-18305 diakses pada hari 7 Februari 2021 Pukul. 01.23

${ }^{19}$ Op.cit, "Tinjauan Yuridis Perkara Pembatalan Hibah (Studi Kasus Putusan Nomor 467 K/Ag2017).” Al-Mizan: Jurnal Hukum dan Ekonomi Islam, 4(2), pp.108-130. 
samping pengumumam tersebut dalam pasal 616. Semua pemindahtanganan, hipotik atau lain-lain beban kebendaan yang dibuat terkemudian dari pada pendaftaran oleh si penerima hibah sebagaimana disebutkan di atas adalah batal, apabila tuntutan sebagai akibat penarikan kembali itu dikabukan.",

Dalam pasal diatas, diterangkan bahwa pengecualian yang terdapat pada pasal $1688 \mathrm{KUH}$ Perdata, dalam hal penerima hibah sudah mendaftarkan hibah, apabila saat akta sudah terbit kemudian timbulah gugatan atas akta tersebut, dan dalam gugatan tersebut terdapat permohonan pembatalan, maka hibah tersebut dianggap batal.

Dengan adanya aturan seperti diatas, ada beberapa hal yang tidak dimasukan kedalam pengecualian pembatalan hibah tersebut. Pada prakteknya, majelis hakim juga sering mengabulkan permohonan pembatalan hibah jika dalil yang diberikan masuk akal dan tidak bertentangan dengan peraturan perundang-undangan yang berlaku saat ini. Terdapat beberapa contoh kasus yang pada saat pemutusan perkara, hakim mengabulkan permohonan pembatalan hibah tersebut. Dalam kasus tersebut hakim menjelaskan bahwa Penggugat merupakan ahli waris dari pasangan suami istri Almarhum Hj. Sarinoh yang telah meninggal dunia pada tanggal 23 Februari 2013, di Cikarang, Ds. Karang Asih. Setelah orang tua Penggugat yang bernama $\mathrm{Hj}$. Sarinoh meninggal dunia, maka Penggugat adalah para ahli waris dari Almarhum Hj. Sarinoh, Berdasarkan Surat keterangan waris tanggal 21 September 2015, yang disaksikan oleh Ketua RT.02 dan Ketua RW 04, serta diketahui oleh Lurah / Kepala desa Cikarang Kota dan Camat Kecamatan Cikarang Utara. Orang tua Penggugat $\mathrm{Hj}$. Sarinoh (Almarhum semasa hidupnya meninggalkan sertifikat hak milik No.5083 atas nama $\mathrm{Hj}$. Sarinoh Luas tanah $500 \mathrm{~m} 2$ dan satu bidang tanah rumah dan bangunan permanen yang terletak di A. Setiabudi No. 17, RT 003, RW 006, Desa Karang Asih, Kecamatan Cikarang Utara, Kabupaten Bekasi. Orang tua Penggugat yang bernama Hj. Sarinoh selama hidupnya memberikan izin untuk anaknya yang bernama Welly Tangkuman S.E untuk menempati tanah serta rumah permanen yang berada di atasnya. Welly Tangkuman sendiri mempunyai seorang istri yang bernama Suryani (Tergugat 1 ). Setelah Welly Tangkuman meninggal dunia, rumah beserta tanah yang telah disebutkan diatas masih dalam penguasaan istri dari welly tangkuman.

Istri dari welly tangkuman bersikeras mempertahankan tanah dan bangunan rumah tersebut sebagai milik suaminya, dengan dalil bahwa saat orang tua penggugat masih hidup tanah tersebut telah dialihkan kepemilikan haknya atau telah dihibahkan kepada suaminya yaitu welly tangkuman. Hibah tersebut juga telah dibuatkan akta nya dengan nomor akta 144/2009 tertanggal 28 Mei 2009 atas nama Hj. Sarinoh memberikan hibah kepada Welly Tangkuman tersebut. Menurut para ahli waris, H. Sarinoh tidak pernah datang menandatangani akta hibah tersebut. Sehingga hal tersebut dapat membuat akta tersebut cacat hukum atau batal demi hukum. Terbitnya akta hibah tersebut tidak diketahui dan tidak seijin suami dari Hj. Sarinoh. Dalam kasus ini hakim melihat dari berbagai aspek dalam pemutusan kasus ini, dikarenakan salah satu syarat hibah tidak terpenuhi dalam kasus diatas, karena tanah dan bangunan tersebut merupakan harta bersama. ${ }^{20}$

Pembatalan pemberian hak atas tanah sendiri telah diatur di Peraturan Menteri Agraria No. 9 Tahun 1999 tentang tata cara pemberian dan pembatalan hak atas tanah negara dan hak pengelolaan. Pada pasal 1 angka 14 Undang-undang, pembatalan hak atas tanah memiliki pengertian "pembatalan keputusan pemberian suatu hak atas tanah atau sertipikat atas tanah karena keputusan tersebut mengandung cacat hukum administrasi dalam penerbitannya atau untuk melaksanakan putusan pengadilan yang telah memperoleh kekuatan hukum yang tetap". Oleh karena itu, karena pada kasus diatas mengandung cacat hukum, maka pembatalan hibah tersebut dapat dilaksanakan.

Pembatalan hak atas tanah karena cacat hukum administratif, dalam penerbitannya dapat dilakukan karena permohonan yang berkepentingan, yang dalam kasus diatas adalah ahli waris dari pemilik hak atas tanah yang seharusnya. Permohonan tersebut dapat ditujukan langsung atau diajukan kepada Menteri atau pejabat kantor pertanahan dimana obyek hak tersebut terletak. "Yang termasuk kedalam cacad administratif menurut Pasal 10 Permen Agraria No. 9 tahun 1999 adalah:

a. Kesalahan prosedur

b. Kesalahan penerapan peraturan perundang-undangan

c. Kesalahan subjek hak

d. Kesalahan jenis hak

e. Kesalahan perhitungan luas

f. Terdapat tumpang tindih ha katas tanah

g. Kesalahan lainnya yang bersifat hukum administrasif"

Terlepas dari tertulis atau tidaknya alasan pembatalan hak atas tanah dalam hal ini adalah hibah dalam suatu kasus pada Permen No.9 Tahun 1999 tentang tata cara pemberian dan pembatalan hak atas tanah negara dan pengelolaannya, jika alasan dalam suatu kasus tersebut dapat dipertanggungjawabkan oleh pihak yang mengajukan 
gugatan maka alasan tersebut dapat dipertahankan untuk melakukan pembatalan hibah. Ada 2 alasan pembatalan hak yaitu mengenai pemohon dan mengenai tanahnya nomor/ jenis hak tanah.

\section{SIMPULAN}

Menurut Undang-Undang Nomor 24 Tahun 1997 tentang Pendaftaran Tanah, hibah harus dituangkan dalam akta otentik. Tetapi masih banyak pula hibah yang dibuat berdasarkan akta bawah tangan. Akta hibah bawah tangan memiliki legalitas yang kurang sempurna dibandingkan dengan akta otentik. Pembuktian akta hibah bawah tangan hanya dapat dipastikan keasliannya apabila tanda tangan tersebut diakui oleh yang menandatangani, jika tanda tangan pada akta hibah bawah tangan tersebut disangkal oleh orang yang menandatangani maka hibah dapat dikatakan tidak sah. Kekuatan pembuktian atau keabsahan akta dibawah tangan dapat menjadi mutlak apabila akta tersebut dilegalisasi oleh Notaris. Umumnya, akta dibawah tangan akan dibuat terlebih dahulu oleh masing-masing pihak. Setelah itu, baru ditandatangani di depan pejabat yang berwenang. Tanggung jawab para pihak hanya ada pada akta yang mereka buat, sedangkan notaris yang menyaksikan penandatanganan akta tersebut hanya bertanggung jawab atas keabsahan tanda tangan para pihak tersebut.

Dalam hal syarat-syarat hibah tidak terpenuhi, pada pasal 1688 KUH Perdata, disebutkan bahwa hibah yang sudah diberikan tidak dapat ditarik kembali, kecuali jika hibah tersebut tidak memenuhi syarat-syarat sah hibah, jika penerima hibah melakukan kejahatan yang membahayakan nyawa si penerima hibah dan apabila jika penerima hibah menolak memberikan tunjangan nafkah kepada si pemberi hibah ketika si pemberi hibah jatuh miskin atau saat ekonominya menurun. Apabila si penerima hibah melakukan salah satu hal yang disebutkan pada pasal tersebut, maka hibah dapat dibatalkan atau ditarik kembali. Pada prakteknya, hal yang dapat membatalkan hibah bukan saja diakibatkan karena yang telah disebutkan pada pasal 1688 diatas, tetapi hibah yang dapat ditarik kembali dapat terjadi karena adanya cacat administratif, melebihi batas yang seharusnya dapat di hibahkan, dan lain sebagainya.

\section{DAFTAR PUSTAKA}

Abdulkadir Muhammad, Hukum dan Penelitian Hukum, Cet. 1. (Bandung: PT. Citra Aditya Bakti, 2004)

Awaliyah, Robiah. and Nadjematul Faizah.,. "Tinjauan Yuridis Perkara Pembatalan Hibah (Studi Kasus Putusan Nomor 467 K/Ag2017).” Al-Mizan: Jurnal Hukum dan Ekonomi Islam, 4(2), pp.108-130.

Harsono, Boedi, Hukum Agraria Indonesia, Sejarah Pembentukan Undang-Undang Pokok Agraria, Isi Dan Pelaksanaannya, Jilid I, Edisi Revisi, Cetakan Kesebelas, (Jakarta : Djambatan, 2007)

Intan.Siti Nurul dan Wardani Rizkianti. "Studi Komparatif Pendaftaran Hak Tanggungan Di Kota Bogor Dan Kota Depok", Jurnal Yuridis, Vol.6, No.2 (2019): 191

Palit. Richard Cisanto, "Kekuatan Akta di Bawah Tangan Sebagai Alat Bukti di Pengadilan. Lex Privatum" (2015) 3(2).

Perangin. Effendi, Mencegah Sengketa Tanah, (Jakarta: Rajawali, 1990)

Peraturan Menteri Negara Agraria No. 9 Tahun 1999 tentang Tata Cara Pendaftaran dan Pembatalan Hak Atas Tanah Negara dan Hak Pengelolaan

Peraturan Pemerintah Nomor 24 Tahun 1997 Tentang Pendaftaran Tanah

Purnamasari. I. D, 2015, Akta Notaris Sebagai Akta Otentik., dalam https://www.hukumonline.com/klinik/detail/ulasan/lt550c0a7450a04/akta-notaris-sebagai-akta-

otentik/\#: :text=\%E2\%80\%9CSuatu\%20akta\%20otentik\%20adalah\%20suatu,kumulatif\%20atau\%20harus\%2 Omeliputi\%20semuanya.

Putusan Pengadilan Negeri Cikarang, No:90/Pdt.g/2020/PN.Ckr, tentang hibah waris

Rumah.com, 2019, Panduan Pendaftaran Tanah Sesuai PP 24 Tahun 1997, diakses pada https://www.rumah.com/panduan-properti/panduan-pendaftaran-tanah-sesuai-pp-24-tahun-1997-18305

Sutedi, Ahmad., Sertifikat Hak Atas Tanah, (Jakarta: Sinar Grafika, 2017)

Tjukup. I Ketut , Layang. I wayan Bela Siki, dkk. "Akta Notaris (Akta Otentik) Sebagai Alat Bukti Dalam Peristiwa Hukum Perdata”, Acta Comitas Jurnal Hukum Kenotariatan, vol.1 no.6 (2016)

Undang-undang Nomor 5 Tahun 1960 tentang Pokok-Pokok Agraria

Waskito,dkk. Pertanahan, Agraria, dan Tata Ruang. (Jakarta: Kencana, 2017),

Yusrizal Kiagus., "Tinjauan Hukum Terhadap Kekuatan Pembuktian Akta Di Bawah Tangan Dihubungkan Dengan Kewenangan Notaris Dalam Pasal 15 Ayat (2) Uu Nomor 30 Tahun 2004 Tentang Jabatan Notaris “ (Doctoral dissertation, program Pascasarjana Universitas Diponegoro). (2008) 